\title{
Health Profile of Workers from a Federal Institute of Education Campus in the State of Goiás, Brazil
}

\author{
Carlos Henrique Pereira Bento, Priscilla Rayanne e Silva Noll, Guilhermy Camargo, Matias Noll \\ Instituto Federal Goiano, Campus Ceres, IF Goiano, Ceres, Brazil \\ Email: matiasnoll@yahoo.com.br
}

How to cite this paper: Bento, C. H. P., Noll, P. R. S., Camargo, G., \& Noll, M. (2018). Health Profile of Workers from a Federal Institute of Education Campus in the State of Goiás, Brazil. Creative Education, 9, 2435-2444.

https://doi.org/10.4236/ce.2018.915183

Received: August 6, 2018

Accepted: November 11, 2018

Published: November 14, 2018

Copyright $\odot 2018$ by authors and Scientific Research Publishing Inc. This work is licensed under the Creative Commons Attribution International License (CC BY 4.0).

http://creativecommons.org/licenses/by/4.0/

\begin{abstract}
This study was an evaluation of the health profile of workers at a campus of the Institute of Education in the state of Goiás, Brazil. All workers were invited to participate. Nine questionnaires were used, with questions focusing on musculoskeletal symptoms, postural habits, physical activity level, dietary habits, quality of life, quality of life at work, quality of sleep, and anthropometric assessment. The results indicated that $77.3 \%$ of evaluated workers consider themselves to be in good health. In addition, workers reported a good self-perception of health. With regards to sleep time, $66.7 \%$ reported sleeping 6 hours or less per night, which is considered inadequate. We found that $53.6 \%$ of participants did not perform any physical activity, and the lack of such practices can compromise their professional and personal life. To ensure improved professional performance, it is important to prioritize the welfare of workers so that there is a balance between the quality of life of workers and their workplace.
\end{abstract}

\section{Keywords}

Quality of Life, Evaluation, Assessment of the Health Profile, Behavioral Relationships, Working Conditions

\section{Introduction}

The number of health problems caused by chronic diseases has risen with industrial advances in society, increasing by $80 \%$ in the adult population. This is due to unfavorable working conditions, which can lead to poor physical and emotional health of workers and, consequently, contribute to the increasing number of workers retiring due to disability or total or partial incapacity (Braga, 2011). 
However, according to Minayo-Gomez and Thedim-Costa (1997), it is important to note that the democratization process in Brazil emerged along with Public Health practices, as well as other public sectors. As a result, several studies were developed in relation to work-health, until this became known as Worker's Health (Silva et al., 2012).

In a recent study, Coêlho et al. (2016) defined disorders relevant to work as clinical presentations acquired through jobs subjected to specific working conditions. Disorders, such as repetitive strain injury (RSI) and work-related musculoskeletal disorders (WMSDs), are considered multifactorial symptoms of psychological, biological, and social origin, categorized as biomechanical, organizational, psychosocial, environmental and individual factors (Signori et al., 2004).

When considered in the context of possible disturbances to workers' health, musculoskeletal disorders and complications have recently been placed at the end of occupational disease indicators. Most occupational disorders can be resolved with simple interventions, such as postural adaptations at work and a willingness to sit in more functional and favorable positions (Renner, 2005).

In a case report, Mendes and Casarotto (1998) stated that regardless of the presenting pathologies, symptoms exhibited by workers are frequently and mistakenly analyzed and understood as physical discomfort. These symptoms can intensify over time, becoming chronic, and may cause functional limitations and interfere with daily work activities. When limited to specific tasks due to work-related disorders, workers may feel incompetent; this may result in physical symptoms affecting psychosocial well-being, since these individuals may experience social prejudice.

Candotti et al. (2011) noted that entrepreneurs began to use exercise in the workplace as a means of preventing such problems and minimizing absences resulting from RSI and WMSDs, medical certificates, accidents at work, and improving productivity growth (Pressi \& Candotti, 2005). It is well known that political actions alongside health measures provide benefits, going beyond the specificities of the sector, improving worker well-being and subsequently increasing productivity of employment, income, and innovation (Gadelha \& Costa, 2012).

The objective of this study was to evaluate the health profile of workers at a campus of the Institute of Education in the state of Goiás, assessing postural patterns and habits in daily life and physical activity.

\section{Methods}

A cross-sectional study was administered to the working population at a campus of the Institute of Education in the state of Goiás, Brazil. All workers at this institution were invited to participate in the study. This institution currently has 205 workers. The workers have working hours of 30 and 40 hours per week. This research was conducted in the years 2016 and 2017.

The present study consisted of 2 steps: 


\subsection{Step 1}

- Development of a website, taking into account all necessary requirements

Website development by a web developer was an integral part of this study, and was also included in another investigation conducted in parallel to this study, entitled "Informatics applied to health and promotion: online platform for filling in questionnaires." System requirements were defined as follows: to enable the completion of the questionnaires by workers, easy navigation and access, and an efficient database. After the creation of the website, online tests were conducted by responsible researchers and participants, as well as by staff personnel of the institution, in order to evaluate the website for questionnaire layout, questionnaire interface, and grammatical errors, as described by Camargo et al. (2018).

Each questionnaire contained important study information, including postural habits, quality of life, quality of life at work, dietary habits, quality of sleep, emotional state, musculoskeletal symptoms, and health quality of workers. These questionnaires were used to identify the health profile of workers from the evaluated institution (Table 1).

\subsection{Step 2}

\section{- Employee registration and completion of the online questionnaires}

The link to the website was sent to workers via their institutional e-mail by the Social Communication and Events Advisory. The e-mail invited all workers at the campus to participate in the research. It contained information and the address to perform the registration. All workers had to register and verify their e-mail address before answering the questionnaires. These were organized sequentially for participants to the study.

After evaluating the data collected, data were tabulated and analyzed using descriptive statistics. All participants agreed to voluntarily participate in the study and signed an informed consent form. This project was approved by the Ethics Committee of the Instituto Federal Goiano (No 035/2014).

Table 1. Details of the 9 questionnaires used for data collection.

\begin{tabular}{ccc}
\hline Subject & Number of questions & Average time to complete \\
\hline Dietary habits & 17 & 3 minutes \\
Postural habits & 20 & 2 minutes \\
Musculoskeletal symptoms & 27 & 3 minutes \\
Physical activity & 8 & 2 minutes \\
General health & 26 & 4 minutes \\
Quality of sleep & 13 & 2 minutes \\
Quality of life at work & 16 & 2 minutes \\
Quality of life & 36 & 4 minutes \\
Site assessment & 10 & 2 minutes \\
TOTAL: 9 questionnaires & $\mathbf{1 7 3}$ questions & $\mathbf{2 4}$ minutes
\end{tabular}




\section{Results}

Questionnaire data were assessed, thus it was possible to ensure that approximately $77.3 \%$ of evaluated workers consider their health as good, as shown in Figure 1. Although workers reported a good self-perception of health, workers reported inadequate sleeping time, as $66.7 \%$ reported sleeping 6 hours or less per night (Figure 2). In addition, with regards to regular physical activity, our findings showed that $53.6 \%$ of workers did not perform any exercise (Figure 3 ).

As shown in Figure 4, the majority of the workers consumed breakfast every day. However, only $20 \%$ consumed fresh fruits as part of their regular diet, as shown in Figure 5.

As shown in Figure 6, approximately $60 \%$ of workers reported that they had inappropriate posture when sitting at the computer. More than $60 \%$ of workers reported strong back pain, as shown in Figure 7.

In agreement with the previous table, Figure 8 shows that approximately $25 \%$ of workers use sleep medications, when sporadic use and use 3 or more times a week are considered together.

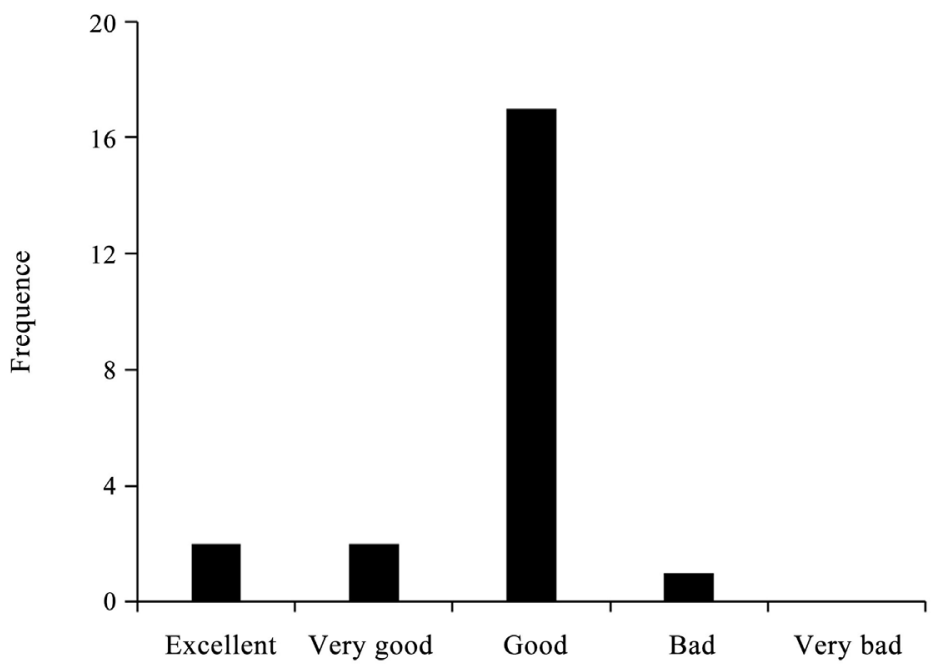

Figure 1. Health self-assessment by workers.

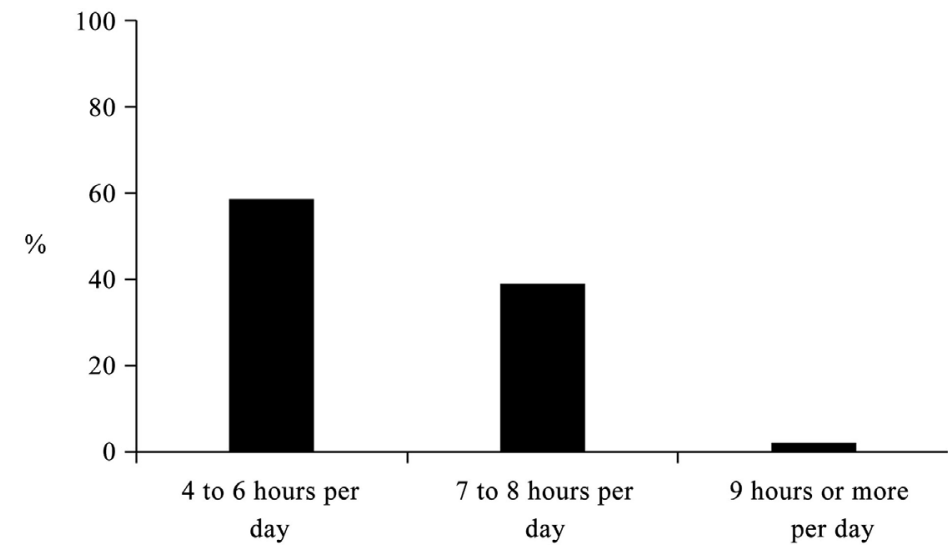

Figure 2. Number of sleeping hours per night reported by workers. 


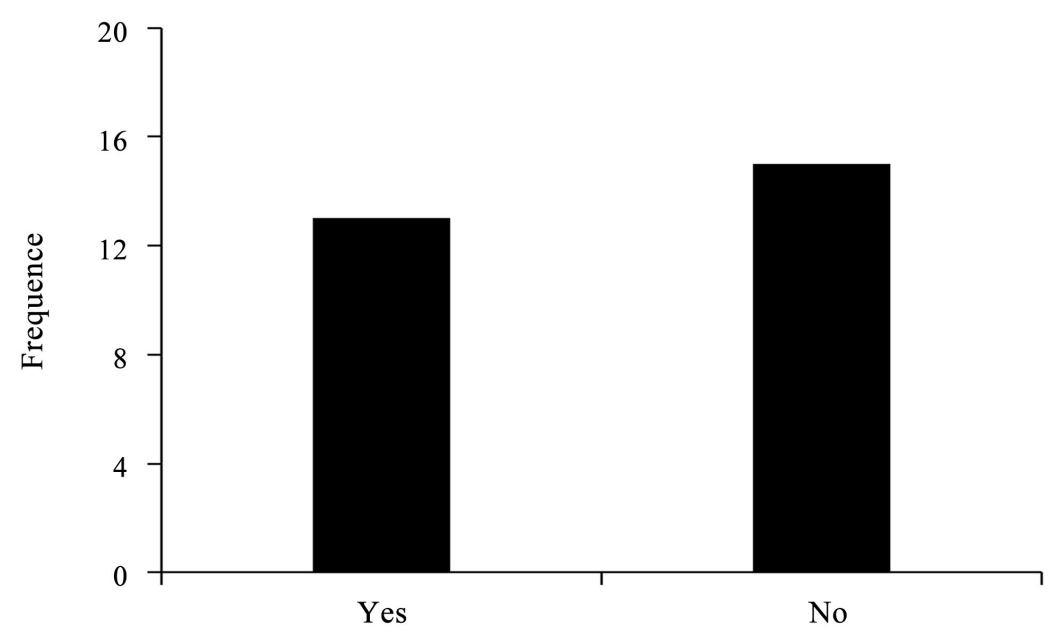

Figure 3. Regular physical exercise reported by workers.

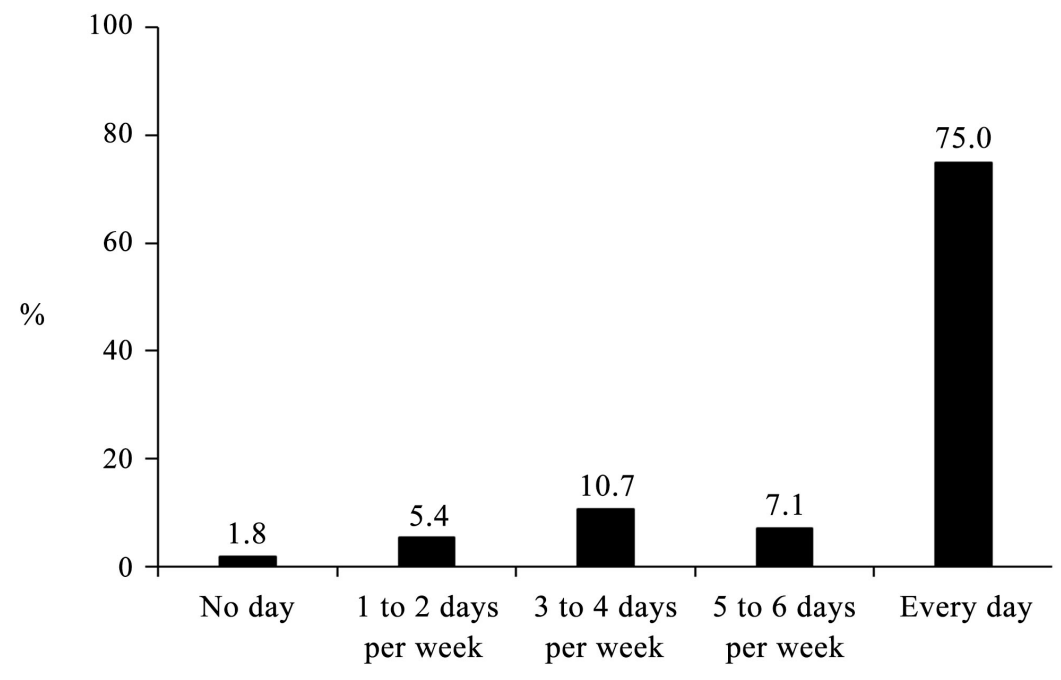

Figure 4. Breakfast consumption reported by workers.

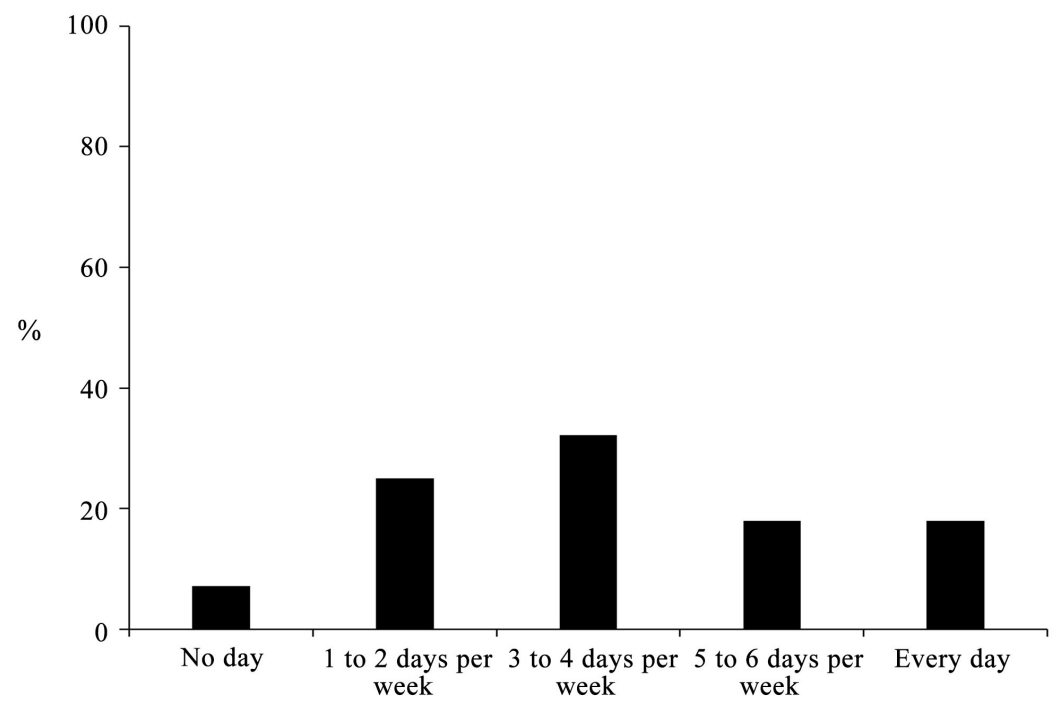

Figure 5. Consumption of fresh fruit reported by workers. 


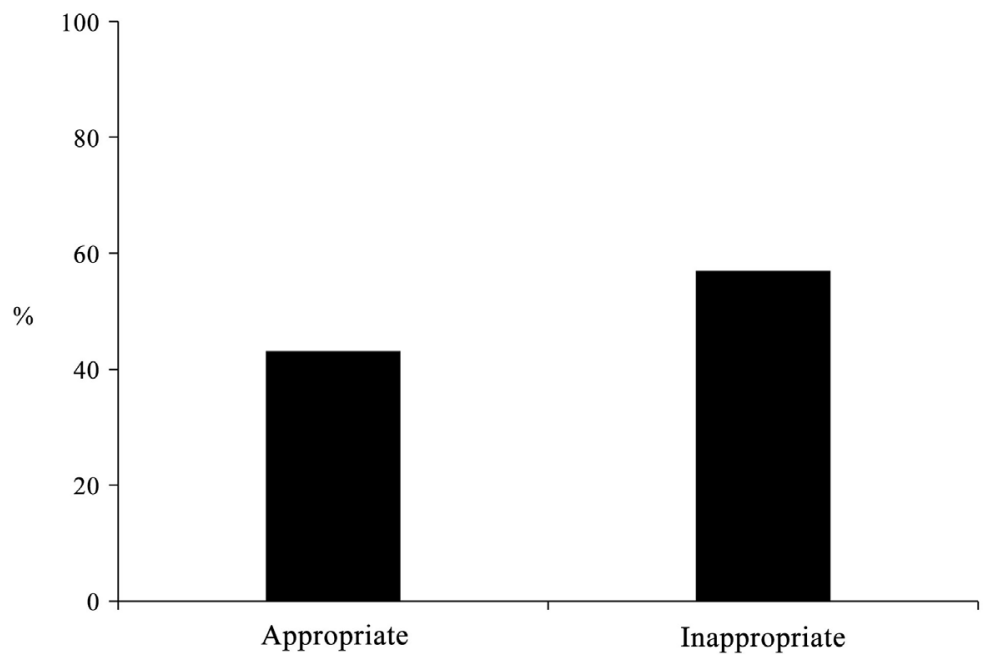

Figure 6. Classification of sitting posture when using the computer.

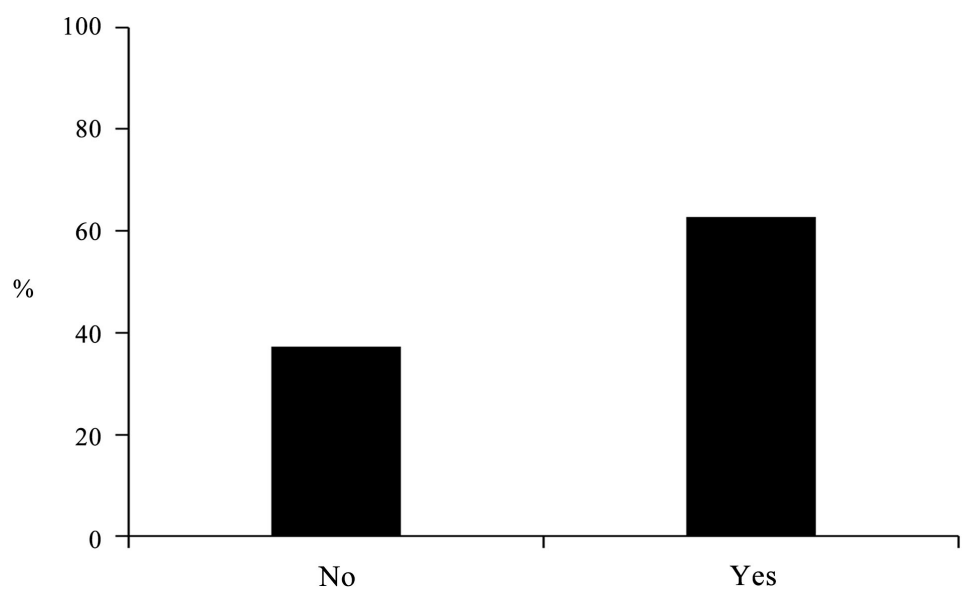

Figure 7. Back pain reported by workers.

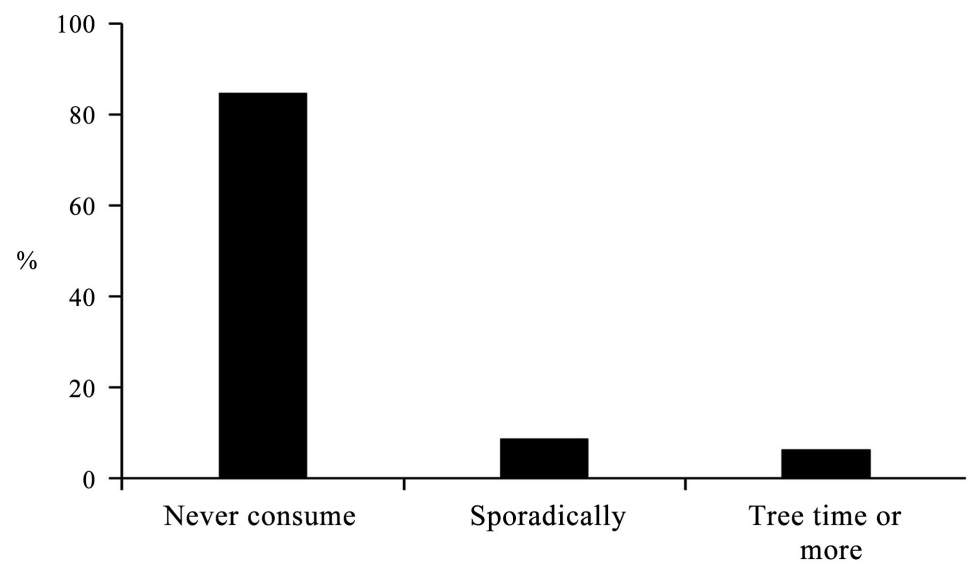

Figure 8. Reported use of sleep medications by workers.

\section{Discussion}

The results presented herein indicate that health education programs are important when building new health care guidelines, to ensure that individuals under- 
stand the position of the guidelines and how guidelines can be integrated into their own lives. Therefore, theoretical and technical solutions for workers with difficulties are required that meet social, political, and public health commitments, whilst overcoming personal and social complications (Ribeiro \& Oliveira, 2005). It is important to emphasize that access to services, in addition to the organizational and dynamic aspects of work, are fundamental contributions to the analyses of geographic, socioeconomic, and other aspects, which are essential to develop perspectives on integral healthcare (Souza et al., 2008).

In Brazil, several studies have used health as an important indicator of quality of life; however, in international studies, such as in the Latin-American Journal of Psychology, quality of life is defined as the existence of objective (social indicators) and subjective aspects (emotional well-being, material well-being, health, labor and other forms of productive activities, family relations, safety, and integration with the community) (Ardila, 2003). Oliveira and Murofuse (2001) noted that, in general, the majority of evaluated workers consider their health status to be good, and few workers state that they have poor health status. This may be because workers do not want to be socially exposed, and is an attempt to convince themselves of their own health status.

Studies indicate that symptoms of disorders increase with age; thus, the development and promotion of preventative actions, as well as social and educational interventions, is important to prevent the emergence of occupational problems that may become permanent overtime (Xavier et al., 2013). Similarly, Paschoal and Tamayo (2005) added that family-work interference can directly influence the development of occupational stress (Ganster \& Schaubroeck, 1991). According to the governmental agency responsible for the quality of health in the Brazilian State, proposals for the prevention and control of occupational diseases are being developed. This allows for the promotion of health at work, especially with older individuals, and to articulate political actions that lead to the improvement of living conditions and quality of life (Ministro da Saúde, 2010).

In recent surveys, Lancman and Ghorardi (2002) also demonstrated that these changes have an impact on the work lives of individuals. Several studies and interventions are been developed to improve the productivity and quality of life of workers, reducing psychological and physiological effects. Moreover, the recovery of workers is both physical and professional, and factors affecting the difficulties faced must be eradicated from the work environment (Lundstrom et al., 2002). It is essential that company workplaces should promote actions to correct or improve risk factors of environments for workers (Schettino, 2016).

Holding a worker responsible for an accident or intrinsic event may be negatively impact the development of workers, inhibiting their psychosocial or organizational development (Reinhardt \& Fischer, 2009). For these reasons, studies performed in the area of life and health quality are more complex and require further investigation. This is due to intervening factors that can compromise the data obtained. Thus, it is important to consider actions that need to be underta- 
ken and information to be collected, so that this does not oppress and inhibit the worker (Grande et al., 2013).

Health problems may be prevented through adequate care of oneself and by practicing healthy habits, potentially resulting in improved life expectancy. Thus, the benefits achieved through physical activity can be physical, social, and psychological (Penedo \& Dahn, 2005). Physical activity may be undertaken as an individual's conscious initiative. As already observed, the health of workers is a collective process, which takes place in a socially established relationship between physicians and workers (Oliveira, 2005).

The results of this study are being used for current and future interventions, including informative booklets, lectures, and exams. These interventions will guide workers and ensure they are aware of the importance of postural habits, proper diet, sufficient sleep, and physical activity in the prevention of chronic disorders that can impair their quality of life, well-being, and professional activities. This may reduce the burden of chronic diseases and disorders. This analysis highlights the need to intensify and prioritize health education, promote and raise awareness of the importance of individual and workplace health.

\section{Conclusion}

The prevalence of unhealthy habits, such as an improper diet with low fruit consumption, inadequate sleep, and poor posture, may impact the quality of life, well-being, and consequently, workers' productivity.

\section{Acknowledgements}

We thank the National Council for Scientific and Technological Development (CNPq, http://cnpq.br/) and the Goiano Federal Instituto (IF Goiano, https://www.ifgoiano.edu.br/home/) for their confidence, support, and the opportunity to undertake this study.

\section{Conflicts of Interest}

The authors declare no conflicts of interest regarding the publication of this paper.

\section{References}

Ardila, R. (2003). Calidad de vida: Una definición integradora. Revista Latinoamericana de Psicologia, 35, 161-165.

Braga, R. M. (2011). Efetividade da escola postural na diminuição da dor crônica: Uma revisão sistemática. 31 f. Monografia (Bacharel em Educação Física), Escola de Educação Física, Universidade Federal do Rio Grande do Sul. Porto Alegre. https://www.lume.ufrgs.br/bitstream/handle/10183/32340/000786394.pdf?sequence=1

Camargo, G., Noll, P. R. S., Bento, C. H. P., \& Noll, M. (2018). Informatics Applied to Health and Promotion: Online Platform for Filling in Questionnaires. Revista Interdisciplinar de Promoção da Saúde, Santa Cruz do Sul, 1, 70-76.

Candotti, C. T., Stroschein, R., \& Noll, M. (2011). Efeitos da ginástica laboral na dor nas 
costas e nos hábitos posturais adotados no ambiente de trabalho. Revista Brasileira de Ciências do Esporte, 33, 699-714.

Coêlho, V., Gaudêncio, K., Santos, M., \& Fernandes, M. G. (2016). Prevalência de ler/dort e fatores associados no departamento estadual de trânsito de pernanbuco-detran/pe. CONAERG, 3, No. 3. https://doi.org/10.5151/engpro-conaerg2016-6689

Gadelha, C. A., \& Costa, L. S. (2012). Saúde e desenvolvimento no Brasil: avanços e desafios. Revista de Saúde Pública, 46, 13-20. https://doi.org/10.1590/S0034-89102012005000062

Ganster, D. C., \& Schaubroeck, J. (1991). Work Stress and Employee Health. Journal of Management, 17, 235-271. https://doi.org/10.1177/014920639101700202

Grande, A. J., Silva, V., Manzatto, L., Rocha, T. B. X., Martins, G. C., \& Vilela Junior, G. B. (2013). Comparação de intervenções de promoção à saúde do trabalhador: Ensaio clínico controlado randomizado por cluster. Revista Brasileira de Cineantropometria e Desempenho Humano, 15, 27-37. https://doi.org/10.5007/1980-0037.2013v15n1p27

Lancman, S., \& Ghorardi, M. I. G. (2002). Pensando novas práticas em terapia ocupacional, saúde e trabalho. Revista de Terapia Ocupacional da Universidade de São Paulo, 13, 44-50. https://doi.org/10.11606/issn.2238-6149.v13i2p44-50

Lundstrom, T., Pugliese, G., Bartley, J., Cox, J., \& Guither, C. (2002). Organizational and Environmental Factors that Affect Worker Health and Safety and Patient Outcomes. American Journal of Infection Control, 30, 93-106. https://doi.org/10.1067/mic.2002.119820

Mendes, L. F., \& Casarotto, R. A. (1998). Tratamento fisioterápico em distúrbios osteomusculares relacionados ao trabalho: Um estudo de caso. Revista de fisioterapia da Universidade de São Paulo, 5, 127-132.

Minayo-Gomez, C., \& Thedim-Costa, S. M. F. (1997). A construção do campo da saúde do trabalhador: Percurso e dilemas. Cadernos de Saúde Pública, 13, 21-32. https://doi.org/10.1590/S0102-311X1997000600003

Ministro da Saúde. (2010). Política Nacional de Promoção da Saúde (3a Ed., p. 60). Brasília: Ministério da Saúdep. http://bvsms.saude.gov.br/bvs/publicacoes/politica_nacional_promocao_saude_3ed.pd f

Oliveira, B. R. G., \& Murofuse, N. T. (2001). Acidentes de trabalho e doença ocupacional: Estudo sobre o conhecimento do trabalhador hospitalar dos riscos à saúde de seu trabalho. The Revista Latino-Americana de Enfermagem, 9, 109-115. https://doi.org/10.1590/S0104-11692001000100016

Oliveira, E. S. A. (2005). Atividade física habitual e outros comportamentos relacionados à saúde dos servidores da universidade federal de santa catarina: Tendência secular 1994-2004. Dissertação (Mestrado em Educação Física), Florianópolis: Centro de Desportos-Universidade Federal de Santa Catarina. https://repositorio.ufsc.br/bitstream/handle/123456789/102204/221551.pdf?sequence= $\underline{1}$

Paschoal, T., \& Tamayo, A. (2005). Impacto dos valores laborais e da interferência família trabalho no estresse ocupacional. Psicologia: Teoria e Pesquisa, 21, 173-180.

Penedo, F. J., \& Dahn, J. R. (2005). Exercise and Well-Being: A Review of Mental and Physical Health Benefits Associated with Physical Activity. Current Opinion in Psychiatry, 18, 189-193. https://doi.org/10.1097/00001504-200503000-00013

Pressi, A. M. S., \& Candotti, C. T. (2005). Ginástica Laboral (130 p.). São Leopoldo: UNISINOS. 
Reinhardt, É. L., \& Fischer, F. M. (2009). Barreiras às intervenções relacionadas à saúde do trabalhador do setor saúde no Brasil. Revista Panamericana de Salud Pública, 25, 411-417. https://doi.org/10.1590/S1020-49892009000500005

Renner, S. J. (2005). Prevenção de distúrbios osteomusculares relacionados ao trabalho. Boletim da Saúde, 19, 73-80.

http://www.boletimdasaude.rs.gov.br/conteudo/1327/protocolo-de-diagnostico-e-trata $\underline{\text { mento-das-ler-dort }}$

Ribeiro, M. B. S., \& Oliveira, L. R. (2005). Terapia ocupacional e saúde mental: Construindo lugares de inclusão social. Comunicação, Saúde, Educação, 9, 425-431. https://doi.org/10.1590/S1414-32832005000200023

Schettino, S. (2016). Precarização do trabalho: Riscos e agravos à saúde e segurança ocupacional dos trabalhadores na colheita florestal em prioridades rurais. Tese (Doctor Scientiae)—Departamento de Engenharia Florestal, Viçosa: Universidade Federal de Viçosa.

http://www.locus.ufv.br/bitstream/handle/123456789/9375/texto\%20completo.pdf?seq $\underline{\text { uence }=1}$

Signori, L. U., Guimarães, L. B. M., \& Sampedro, R. M. F. (2004). Análise dos instrumentos utilizados para a avaliação do risco da ocorrência dos d.o.r.t/l.e.r. Produto \& Produção, 7, 51-62.

Silva, H. P., Petramale, C. A., \& Elias, F. T. S. (2012). Avanços e desafios da política nacional de gestão de tecnologias em saúde. Revista de Saúde Pública, 46, 83-90.

https://doi.org/10.1590/S0034-89102012005000060

Souza, E. C. F., Vilar, R. L. A., Rocha, N. S. P. D., Uchoa, A. C., \& Rocha, P. M. (2008). Acesso e acolhimento na atenção básica: Uma análise da percepção dos usuários e profissionais de saúde. Cadernos de Saúde Pública, 24, 100-110.

https://doi.org/10.1590/S0102-311X2008001300015

Xavier, I. A. L. N., Santos, A. C. O., \& Silva, D. M. (2013). Saúde vocal do professor: Intervenção fonoaudiológica na atenção primária à saúde. Revista CEFAC, 15, 976-985. https://doi.org/10.1590/S1516-18462013000400027 